\title{
Nucleolar accumulation of Semliki Forest virus nucleocapsid C protein: influence of metabolic status, cytoskeleton and receptors
}

\author{
R. JAKOB
}

Institute for Applied Cell Culture, Balanstr. 6, 81669 Munich, Germany

\begin{abstract}
Summary. The nucleolar accumulation of Semliki Forest Virus (SFV) C protein was examined as a function of intact microtubules, intact microfilaments and accessible intermediate filaments. The cytoskeletal components do not seem to play a role in directing $\mathrm{C}$ protein to the nucleolus but nucleolar accumulation is energy-dependent and saturable. This suggests the involvement of some receptor- (or chaperon-) interaction.
\end{abstract}

\section{Introduction}

Several viral capsid proteins have been shown to migrate to the cell nucleus, ${ }^{1-3}$ where they exert, as yet, poorly understood functions. Semliki Forest Virus (SFV) C protein plays a role in virus-host regulation., ${ }^{4,5}$ Its migration to the nucleolus ${ }^{3}$ might be responsible for this regulatory role. It has been shown recently that the nucleolar accumulation of $\mathrm{C}$ protein is a rapid event, and is complete before host cellular protein synthesis is shut off. ${ }^{6}$ The role of the cytoskeleton in intracellular transport ${ }^{7-12}$ has suggested a possible involvement of cytoskeletal components in $\mathrm{C}$ protein translocation. Furthermore, the speed of accumulation of $\mathrm{C}$ protein suggests the involvement of an energydependent process.

\section{Material and methods}

\section{Preparation of subcellular fractions}

Nucleolar fractions from SVF-infected semiconfluent Vero (African green monkey kidney) cells were prepared and separated by reducing SDS-PAGE, immunoblotted with an affinity-purified anti-C protein antiserum, and visualised by autoradiography. Briefly, cells were grown in $75-\mathrm{cm}^{2}$ plastic culture bottles (Corning, Stone) in DMEM (Biochrom; Berlin, Germany) supplemented with complement-depleted FCS $\left(45 \mathrm{~min}\right.$ at $\left.56^{\circ} \mathrm{C}\right) 10 \%$, penicillin $100 \mathrm{IU} / \mathrm{ml}$, streptomycin $100 \mu \mathrm{g} / \mathrm{ml}$ and $2 \mathrm{~mm}$ glutamine (all Gibco, Paisley). Nucleolar fractions were prepared at $4^{\circ} \mathrm{C}$ by swelling the cells for $10 \mathrm{~min}$ in $10 \mathrm{~mm}$ Tris- $\mathrm{HCl}$, pH 7.4, $10 \mathrm{~mm} \mathrm{NaCl}, 1.5 \mathrm{~mm} \mathrm{MgCl}_{2}$ (all from Merck, Darmstadt, Germany) supplemented with $50 \mathrm{~mm}$ iodoacetamide, aprotinin (Sigma, Munich, Germany) $20 \mu \mathrm{g} / \mathrm{ml}$ and $1 \mathrm{~mm}$ phenyl methyl sulphonyl fluoride

Received 17 May 1993; revised version accepted 1 Dec. 1993.
(PMSF; Boehringer Mannheim, Germany). Cells were disrupted in a Dounce homogeniser. The lysate was centrifuged for $8 \mathrm{~s}$ in an Eppendorf-Microfuge at $12000 \mathrm{~g}$. The resultant post-nuclear supernate was termed cytoplasmic extract. The pellet was passed through a needle $(0.45-\mathrm{mm}$ gauge), layered on top of a $0.7-\mathrm{ml}$ sucrose $45 \% \mathrm{w} / \mathrm{v}$ cushion in the hypotonic swelling buffer and pelleted for $30 \mathrm{~min}$ at $1700 \mathrm{~g}$. After washing twice in the same buffer, the resultant nuclei were sonicated at $140 \mathrm{~W}$ for $1 \mathrm{~min}$ in $0.34 \mathrm{M}$ sucrose, $0.05 \mathrm{mM} \mathrm{MgCl}_{2}, 10 \mathrm{~mm}$ triethanolamine (all Merck, Darmstadt, Germany), $\mathrm{pH} 7 \cdot 4$. The debris was centrifuged for $15 \mathrm{~min}$ at $12000 \mathrm{~g}$, the nucleolar pellet was resuspended in swelling buffer and layered on top of a $0 \cdot 2-\mathrm{ml}$ sucrose cushion to be centrifuged as above. The pellet represented the purified nucleoli.

\section{Quantitative Western blotting}

Cells were infected with increasing concentrations of SFV (isolated from Vero cells according to the method of Kääriäinen and Gomatos ${ }^{13}$ ) and the nucleoli were isolated as described above, or nucleoli were incubated directly for $1 \mathrm{~h}$ with SFV C protein (isolated according to the method of Omar and Koblet $^{14}$ ) and washed three times in swelling buffer before non-reducing PAGE on $12.5 \%$ gels $^{15}$ and Western blot analysis according to the method of Towbin et al ${ }^{16}$ After electroblotting the relevant $\mathrm{C}$ protein bands were revealed with affinity purified anti$\mathrm{C}$ protein antibodies and ${ }^{125}$ I-labelled second antibody. ${ }^{6}$ Autoradiographs were exposed for up to 3 weeks and the bands representing the $\mathrm{C}$ protein were scanned with a BioRad 620 densitometer with white light (BioRad, Richmond, CA, USA) to yield $\mathrm{OD} \times \mathrm{mm}$ as a measure of the amount of $\mathrm{C}$ protein. Serial dilutions of $\mathrm{C}$ protein or SFV were treated in an identical manner and served as an internal standard to correct for variations in electroblotting efficiency, 

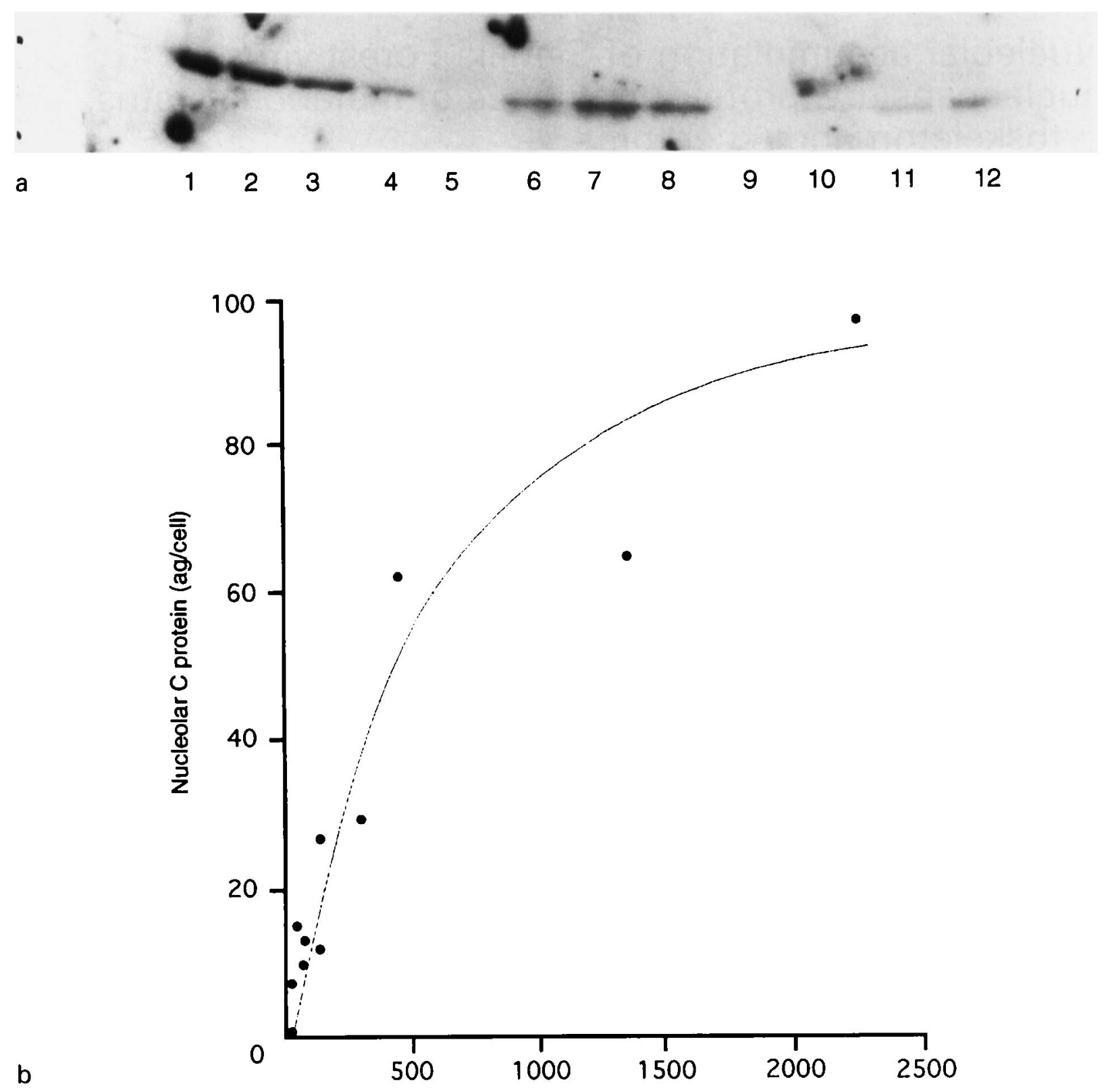

\section{C protein applied by natural infection (ag/cell)}

Fig. 1. a, Anti-C protein immunoblot of nuclear and cytoplasmic fractions of SFV-infected Vero cells infected for $3 \mathrm{~h}$ after addition of cycloheximide $500 \mu \mathrm{g} / \mathrm{ml}$ in complete DMEM-medium with increasing concentrations of SFV. Lanes 1-4: standard dilutions of virus corresponding to $1,180 \mathrm{pg} ; 2,90 \mathrm{pg} ; 3,45 \mathrm{pg} ; 4,23 \mathrm{pg}$ of C protein. Lanes 5-8: whole nucleolar extracts- -5 , control; 6-8 incubated with SFV corresponding to $C$ protein $0.8,1.7$ and $3.9 \mathrm{pg}$ /cell. Lanes 9-12: samples of cytoplasmic extracts $(5 \%)-$ control (9), and incubated with SFV corresponding to C protein $0.8(10) 1.7(11)$ and $3.9(12) \mathrm{pg} / \mathrm{cell}$. b, Nucleolar association of SFV C protein as a function of cytoplasmic C protein. Densitometric evaluation of several immunoblots as shown in fig. 1a to give the correlation between cytoplasmic and nuclear $\mathrm{C}$ protein in response to SFV infection expressed in attograms(ag)/infected cell $(1 \mathrm{pg}=1000 \mathrm{ag})$.

exposure time, specific radioactivity of the second and specific activity of the first antibody. By comparing OD $\times \mathrm{mm}$ values measured with the standard curve of serial dilutions of $\mathrm{SFV}$ or $\mathrm{C}$ protein, absolute $\mathrm{C}$ protein concentration was quantified.

\section{DNAase and RNAase treatment of nucleoli}

Nucleolar fractions were incubated for $30 \mathrm{~min}$ at $37^{\circ} \mathrm{C}$ with a mixture of RNAase A $30 \mu \mathrm{g} / \mathrm{ml}$ and DNAase $50 \mu \mathrm{g} / \mathrm{ml}$ (Boehringer) in $50 \mathrm{~mm}$ Tris- $\mathrm{HCl}$, $\mathrm{pH} 7.8,9 \mathrm{mM} \mathrm{MgCl}_{2}, 10 \mathrm{~mm}$ 2-mercaptoethanol.

\section{Drug treatment of Vero cells before infection}

To assess the role of the actin microfilaments, cells were pre-incubated for $2 \mathrm{~h}$ with $1 \mu \mathrm{M}$ cytochalasin D (Fluka, Buchs, Switzerland) before infection ( $1 \mathrm{~h}$ at $\left.4^{\circ} \mathrm{C}, 5 \mathrm{pfu} / \mathrm{cell}\right)$. Nucleoli were harvested $3 \mathrm{~h}$ after infection (hpi) and the relative $\mathrm{C}$ protein migration was determined by comparison with the positive control.

Nocodazole (33 $\mu \mathrm{m}$; Aldrich, Milwaukee, USA), a microtubule disrupting agent,,${ }^{17,18}$ was applied in the same manner. Pre-treatment of Vero cells with lower 


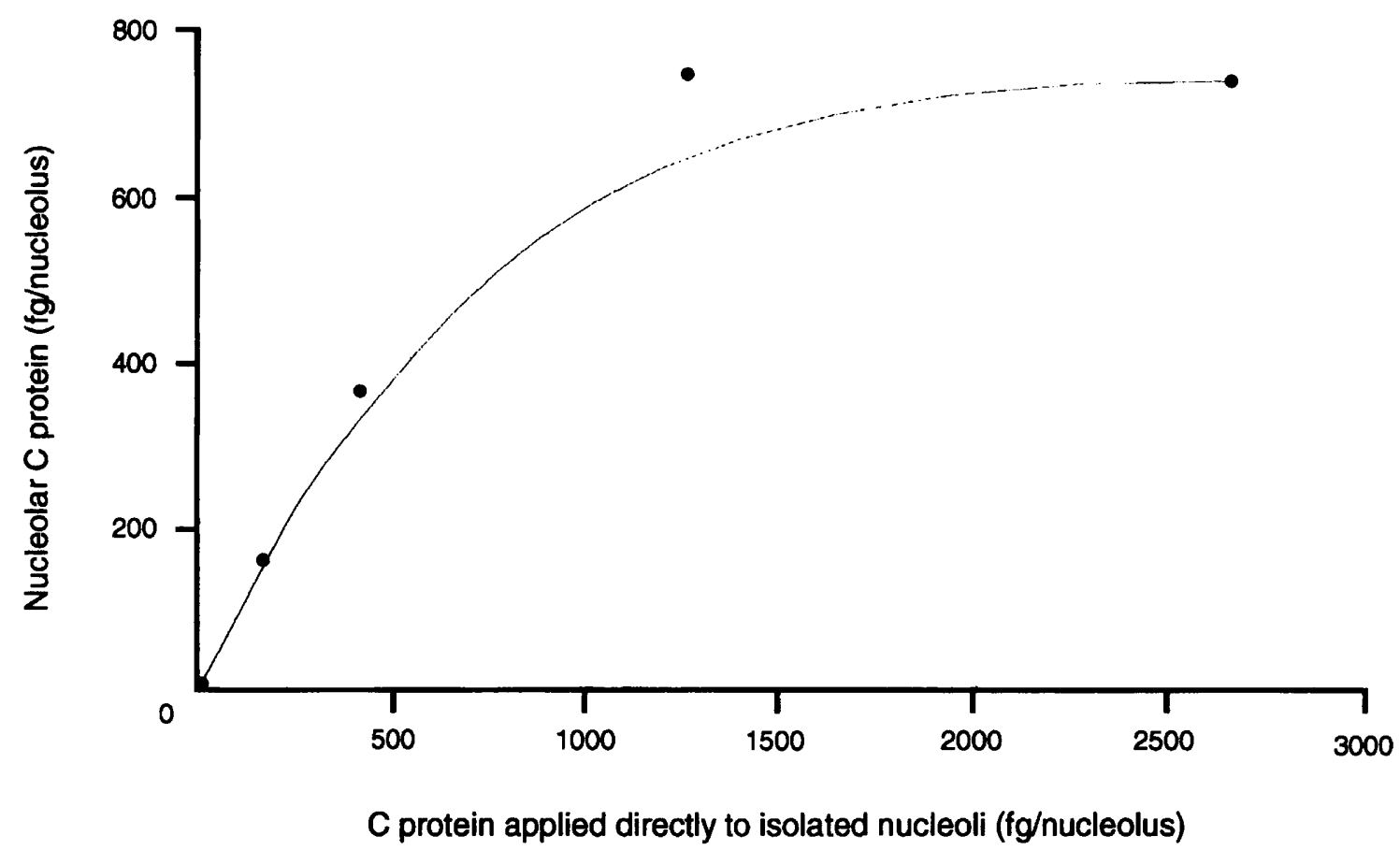

Fig. 2. Nucleolar association of $\mathrm{C}$ protein as a function of $\mathrm{C}$ protein applied directly to isolated nucleoli. One Vero cell nucleus contains an average of 1.3 nucleoli as counted microscopically; $1 \mathrm{ag}=1000 \mathrm{fg}$ (femtogram).

concentrations of nocodazole $(0 \cdot 13 \mu \mathrm{M})$ arrests the cells before mitosis. ${ }^{19}$ Since the effect is reversible, ${ }^{20,21}$ cells proceed spontaneously and simultaneously through mitosis when fresh medium is replaced. Therefore, cells were treated overnight with $0.13 \mu \mathrm{M}$ nocodazole; the medium was then changed and the Vero cells were infected as above to determine the effect of mitosis on nucleolar accumulation of $\mathrm{C}$ protein. Nuclei were again harvested at $3 \mathrm{hpi}$.

ATP-depleted cells were produced by incubation with medium containing $10 \mathrm{~mm}$ sodium azide (Merck) and $6 \mathrm{~mm}$ deoxyglucose (Aldrich). ${ }^{22}$ The pre-incubation time was again $2 \mathrm{~h}$ and nucleoli were harvested at 3 hpi.

The influence of intermediate filaments on the trafficking of $\mathrm{C}$ protein was revealed by electroporating $^{23} 10 \mu \mathrm{l}$ of anti-vimentin antibody (Amersham) into $10^{6}$ Vero cells in $100 \mu \mathrm{l}$ of DMEM and $90 \mu \mathrm{l}$ of electroporation buffer ${ }^{23}$ at $0 \cdot 4 \mathrm{kV}$ and $25 \mu \mathrm{F}$. Cells were plated out for $3 \mathrm{~h}$ and infected overnight. Controls were electroporated without antibody.

\section{Results}

$\mathrm{C}$ protein accumulated in the nucleoli of SFVinfected Vero cells reached a saturation plateau with increasing concentrations of cytoplasmic $\mathrm{C}$ protein (fig. 1a and b). However, if nucleolar extracts were incubated directly with increasing amounts of $\mathrm{C}$ protein, saturation was achieved with about thousandfold lower concentrations of $\mathrm{C}$ protein and at about hundred-fold lower nucleolar concentrations of $\mathrm{C}$ protein (fig. 2). The increased binding of $\mathrm{C}$ protein molecules to purified nucleoli in vivo compared to that to nucleoli isolated after simple incubation with
Table. Effect of chemical treatment on the relative incorporation of SFV C protein into nucleoli

\begin{tabular}{lc}
\hline Treatment & $\begin{array}{c}\text { Nucleolar associated C protein } \\
\text { (percentage of untreated control)* }\end{array}$ \\
\hline Cytochalasin & 100 \\
Nocodazol & 99 \\
Anti-vimentin antibody & 94.5 \\
Mitosis stimulation & 92 \\
ATP-depletion & 7
\end{tabular}

*OD of C-protein bands after Western blot of naturally infected cells was set to $100 \%$ and the OD of treated cells was expressed as a percentage of these untreated controls $(n=2)$.

protein $\mathrm{C}$ could be reversed by DNAase + RNAase treatment of the nucleolar fraction of naturally infected Vero cells (data not shown).

The effect of different drugs that act on the organisation of the cytoskeleton was determined by scanning the $\mathrm{OD}$ of the relevant $\mathrm{C}$ protein bands on Western blots of nucleolar extracts and comparing them with untreated controls. The table summarises the results of these experiments. Interference with cytoskeletal components did not influence markedly migration of the $\mathrm{C}$ protein. In contrast, ATP depletion had a great effect on nucleolar migration. This corresponds with the observation that starving cells fail to incorporate $\mathrm{C}$ protein into their nucleoli (data not shown).

\section{Discussion}

The results of this study show that the cytoskeleton does not play a role in nucleolar accumulation of SFV $\mathrm{C}$ protein. Interestingly, the breakdown of the nuclear 
membranes during mitosis did not lead to increased accumulation of $\mathrm{C}$ protein. Increased accumulation would have been expected because dividing 3T3-L1 cells take up gold particles coupled to the karyophilic protein nucleoplasmin at a rate seven times that of growth-arrested cells. ${ }^{24}$ However, ATP depletion impedes nucleolar migration of SFV C protein dramatically. This finding corresponds to results of an invitro system for the study of C protein karyophilicity. ${ }^{3}$ Although the cytoskeleton does not seem to promote $\mathrm{C}$ protein migration, an association of $\mathrm{C}$ protein with the cytoskeleton during uncoating of the viral nucleocapsid, as found for vesicular stomatitis virus (VSV) N protein, ${ }^{25}$ cannot be excluded. Recently, Singh and Helenius $^{26}$ showed that ribosomes are implicated in

\section{References}

1. McLachlan A, Milich DR, Raney AK et al. Expression of hepatitis B virus surface and core antigens: influences of pre-S and precore sequences. $J$ Virol 1987; 61 : 683-692.

2. Yamauchi $M$, Nishiyama $Y$, Fujioka $H$, Isomura $S$, Maeno $K$. On the intracellular transport and the nuclear association of human cytomegalovirus structural proteins. J Gen Virol $1985 ; 66: 675-684$.

3. Michel MR, Elgizoli M, Dai Y, Jakob R, Koblet H, Arrigo AP. Karyophilic properties of Semliki Forest virus nucleocapsid protein. J Virol 1990; 64: 5123-5131.

4. Van Steeg H, Kasperaitis M, Voorma HO, Benne R. Infection of neuroblastoma cells by Semliki Forest virus: the interference of viral capsid protein with the binding of host messenger RNAs into initiation complexes is the cause of the shut-off of host protein synthesis. Eur J Biochem 1984; 138: $473-478$.

5. Elgizoli M, Dai Y, Kempf C, Koblet H, Michel MR. Semliki Forest virus capsid protein acts as a pleiotropic regulator of host cellular protein synthesis. J Virol 1989; 63: 2921-2928.

6. Jakob R. Nucleolar accumulation of C protein in cells naturally infected with Semliki Forest virus. Quantitative Aspects. Virus Res 1993; 30: 145-160.

7. Bomsel M, Parton R, Kuznetsov SA, Schroer TA, Gruenberg J. Microtubule- and motor-dependent fusion in vitro between apical and basolateral endocytic vesicles from MDCK cells. Cell 1990; 62: 719-731.

8. Herman B, Albertini DF. A time-lapse video image intensification analysis of cytoplasmic organelle movements during endosome translocation. $J$ Cell Biol 1984; 98: 565-576.

9. Matteoni R, Kreis TE. Translocation and clustering of endosomes and lysosomes depends on microtubules. J Cell Biol $1987 ; 105$ : $1253-1265$.

10. De Brabander M, Nuydens R, Geerts H, Hopkins CR. Dynamic behavior of the transferrin receptor followed in living epidermoid carcinoma (A431) cells with nanovid microscopy. Cell Motil Cytoskeleton 1988; 9: 30-47.

11. Matsuuchi L, Buckley KM, Lowe AW, Kelly RB. Targeting of secretory vesicles to cytoplasmic domains in AtT-20 and PC-12 cells. J Cell Biol 1988 ; 106: 239-251.

12. Newmeyer DD, Forbes DJ. An N-ethylmaleimide-sensitive cytosolic factor necessary for nuclear protein import: requirement in signal-mediated binding to nuclear pore. $J$ Cell Biol 1990; 110: 547-557.

13. Kääriäinen L, Gomatos PJ. A kinetic analysis of the synthesis in the uncoating of SFV nucleocapsids and that this process is energy-independent until there is sequestration of the $\mathrm{C}$ protein molecules.

The finding that, in vivo, thousand-fold more $\mathrm{C}$ protein concentrations were needed to saturate the nucleoli with about 100 -fold more C-protein than in vitro reflects the fact that additional substrates for $\mathrm{C}$ protein binding are present inside the infected cell both in the cytoplasmic and nucleolar fractions. The finding that nucleolar accumulation in vivo and in vitro is energy-dependent and saturable argues in favour of a receptor or chaperon being responsible for the migration process.

I am grateful to Rudi Buchheit and all other supporters of my work in Germany and Switzerland.
BHK 21 cells of RNAs specific for Semliki Forest virus. $J$ Gen Virol 1969; 5: 251-265.

14. Omar A, Koblet H. One-step separation of the components of Semliki Forest virus by cation exchange chromatography. $J$ Virol Methods 1985; 12: 71-83.

15. Weber K, Osborn M. Proteins and sodium dodecyl sulfate: molecular weight determination on polyacrylamide gels and related procedures. In: Neurath H, Hill RL (eds) The proteins, 3rd edn, vol 1. New York, Academic Press. 1975: $179-223$.

16. Towbin H, Staehelin T, Gordon J. Electrophoretic transfer of proteins from polyacrylamide gels to nitrocellulose sheets: procedure and some applications. Proc Natl Acad Sci USA $1979 ; 76: 4350-4354$.

17. Bré $\mathbf{M}-\mathrm{H}$, Kreis TE, Karsenti E. Control of microtubule nucleation and stability in Madin-Darby canine kidney cells: the occurrence of noncentrosomal, stable detyrosinated microtubules. J Cell Biol 1987; 105: 1283-1296.

18. Vega-Salas DE, Salas PJI, Gundersen D, Rodriguez-Boulan E. Formation of the apical pole of epithelial (Madin-Darby canine kidney) cells: polarity of an apical protein is independent of tight junctions while segregation of a basolateral marker requires cell-cell interactions. J Cell Biol 1987; 104: 905-916

19. Zieve GW, Turnbull D, Mullins JM, McIntosh JR. Production of large numbers of mitotic mammalian cells by use of the reversible microtubule inhibitor nocodazole. Exp Cell Res $1980 ; 126: 397-405$.

20. Orias E, Flacks M. Use of genomic exclusion to isolate heatsensitive mutants in tetrahymena. Genetics 1973; 73: $543-559$.

21. Sonneborn TM. Recent advances in the genetics of paramecium and euplotes. Adv Genet 1974; 1 : 263-358.

22. Richardson WD, Mills AD, Dilworth SM, Laskey RA, Dingwall C. Nuclear protein migration involves two steps: rapid binding at the nuclear envelope followed by slower translocation through nuclear pores. Cell $1988 ; 52$ : 655-664.

23. Michel MR, Elgizoli M, Koblet H, Kempf C. Diffusion loading conditions determine recovery of protein synthesis in electroporated P3X63Ag8 cells. Experientia 1988; 44: 199-203.

24. Feldherr CM, Akin D. The permeability of the nuclear envelope in dividing and ncndividing cell cultures. J Cell Biol 1990; 111: $1-8$.

25. Rigaut KD, Birk DE, Lenard J. Intracellular distribution of input vesicular stomatitis virus proteins after uncoating. $J$ Virol 1991; 65: 2622-2628.

26. Singh I, Helenius A. Role of ribosomes in Semliki Forest virus nucleocapsid uncoating. J Virol 1992; 66: 7049-7058. 